\title{
Pedagogical System of Continuous Socio- Ecological Education of the Future University Professor
}

\author{
Amina Niyazova ${ }^{1}$, Anvar Khuziakhmetov ${ }^{2, *}$, Rafis Shaimardanov ${ }^{1}$, Olga Balina $^{1}$, and Aram \\ Vartanian $^{3}$ \\ ${ }^{1}$ Surgut State Pedagogical University, Surgut, Russia \\ ${ }^{2}$ Kazan (Volga Region) University, Kazan, Russia \\ ${ }^{3}$ Yugra State University, Khanty-Mansiysk, Russia
}

\begin{abstract}
Education is the leading springboard for the formation of an environmentally cultured and educated person who can live and work in today's rapidly changing society. The environmental crisis and the focus on sustainable development determine the relevance of socio-ecological education in the interests of the Concept of Sustainable Development (1994). The process of professional training of the future professor is based on the Federal State Educational Standard of Pedagogical Education and the professional standard, which defines the universal, general professional, and professional competencies and labor actions of the professor. The lack of special competencies indicates the formation of knowledge, abilities, skills, and experience in the field of socio-ecological education within the framework of general professional and professional competencies. The result of the future professor's readiness for continuous socio-ecological education of students is determined by the socioecological knowledge. The development of socio-ecological knowledge in the conditions of professional training at the university requires the creation of a specific pedagogical system, including forms, methods, technologies, and pedagogical conditions for its development. These conditions include the creation of a socio-eco-oriented educational environment, the integration of formal, non-formal, and informal education, the use of modern digital, information and communication, and educational technologies. The selected components of socio-ecological knowledge: motivational-value, cognitive, activity, and reflexive formed the basis of the experimental study.
\end{abstract}

\section{Introduction}

The progressive and intensive development of modern society is considered as a mechanism in the development of an innovative personality, on the one hand, and as a factor that increases socio-ecological problems, on the other hand. In this situation, the most vulnerable category is students who shall meet the time and conditions of life and, at

*Corresponding author: hanvar9999@mail.ru 
the same time, be morally and spiritually educated individuals who can build relationships and interact in a socio-natural environment. The leading springboard for the formation of a "unique" personality capable of living and working in today's rapidly changing society is education. The relevance and active development of socio-ecological education are associated with the adoption of the Concept of Sustainable Development (1994) and the directions of social development highlighted in it - economic, social, and environmental [1].

Research in the field of continuous socio-ecological education was carried out by both foreign and domestic researchers: N.M. Ardoin [2], O. Siegman [3], C. Galvis-Riaño [4] E.V. Girusov, E.G. Sharonova, V.S. Shilova, etc.

The analysis of the scientific works enabled to identify a number of contradictions in the field of continuous socio-ecological education of the future professor, namely:

- socio-pedagogical, defining the requirements for the personality of a modern highly educated professor, capable of implementing socio-ecological education, on the one hand, and the lack of a holistic pedagogical system in the university, on the other hand;

- scientific and pedagogical, which determine the professional training of professors for pedagogical activities in the field of continuous socio-ecological education, on the one hand, and the lack of special competencies that ensure the readiness of the future professor to implement it, on the other hand;

- scientific and methodological, characterizing the forms, methods, technologies, pedagogical conditions for the development of socio-ecological knowledge of the future professor's personality, on the one hand, and the lack of methods and mechanisms for its development.

All these contradictions determine the relevance of the topic under study and emphasize its practical significance in the professional training of future professors for continuous socio-ecological education.

\section{Materials and Methods}

In the process of theoretical analysis of scientific works, the theoretical and methodological approaches that form the basis of continuous socio-ecological education are identified: coevolutionary, socio-ecological, system and activity, environmental, situational. These approaches allowed identifying the main principles and patterns of continuous socioecological education, which are the basis of the pedagogical system of the university, aimed at developing the socio-ecological knowledge of the future professor. To understand the essence of the process of continuous socio-ecological education, let us turn to the basic concepts of the study.

Thus, the theoretical and methodological elaboration of the concept of "socio-ecological education" is found in the study of E.V. Girusov (2015), where the emphasis is placed on the process of preparing for activities in the natural environment of a person who can act in the environment [5]; V.S. Shilova (2015), who reveals this concept as a purposeful educational process aimed at establishing optimal and harmonious relations in the socionatural environment and its entry into socio-ecological processes [6]. E.G. Sharonova (2011) considers some aspects of socio-ecological education in the concept of "socioecological upbringing" while highlighting socio-ecological knowledge as the main component of socio-ecological education [7].

The analysis of the content of the concept of "socio-ecological education" shows the need for its formation, constant and continuous development in each individual, starting with general education (preschool, primary, basic, and secondary), continuing in professional education. Continuous socio-ecological education with certain vertical and 
horizontal lines, types of education (formal, non-formal, and informal education) is relevant for our study.

Continuous socio-ecological education is considered as a paradigm of scientific and pedagogical thinking and a way of educational activity aimed at the formation of the ecological culture of the individual. Our study has shown that at each of the levels of general education, the result of socio-ecological (ecological) education is an ecological culture. However, the components of ecological culture are filled with certain content and skills that correspond to the age and psychological characteristics of the development of children and students. In the course of the study, we have developed a model of the environmentally cultural personality of a school graduate, which makes the requirements for the professional training of a future professor [8].

Socio-ecological education at the university is based on the content of professional education, forms, and methods, technologies used in the training of future professors. In the process of analyzing the results of socio-ecological education at the university, researchers distinguish: knowledge, environmental culture, personality orientation, competence, etc. [9]. Based on the analysis of the characteristics and components of the above results, we have identified socio-ecological education as the result of preparing the future professor for continuous socio-ecological knowledge. However, the study of this concept has shown that the concept of "knowledge" occurs more as a general category, which denotes the quality of a person, his ability to continuously gain life experience and further develop on its basis. We will highlight several approaches to the concept of "knowledge":

- social, which reveals knowledge as the most important social attribute of every person in society, the presence of which determines the appearance of career prospects and becomes a resource for acquiring higher social statuses;

- psychological, which defines knowledge as the quality of personality that enables to apply the theoretical knowledge gained in practical activities in a socio-natural environment;

- pedagogical, which means that a person actually has a significant volume of knowledge, as well as skills to apply this knowledge in practice.

The analysis of this concept, taking into account the approaches we have identified, enables to designate knowledge as a specific result of a person's education. However, considering the types of knowledge (moral, valeological, social, etc.), we have identified a relevant type for us - ecological.

The analysis of studies on ecological knowledge has shown the lack of its disclosure in psychological and pedagogical research. However, I.P. Safronov, considering the ecological professionalism of the professor, distinguishes ecological knowledge as a system of scientific socio-ecological information about the co-evolution of society and nature, necessary for pedagogical activity with children and students [10]. L.S. Koldamasova distinguishes ecological knowledge of students as a set of knowledge, skills of forming a value attitude to nature [11].

However, it should be noted that the use of the concepts of "knowledge" and "ecological knowledge" in psychological and pedagogical research is limited, which enabled us to consider the socio-ecological knowledge as a result of the future professor's readiness to implement continuous socio-ecological knowledge of students.

Modern studies have no clear interpretation of the concept of "socio-ecological knowledge". Socio-ecological knowledge is the quality of a developing person who has scientific knowledge about nature, the socio-ecological interaction of society and nature, and the ability to use it in practice. We consider the socio-ecological knowledge of the professor in the process of professional training. Due to the lack of this concept in the theory and understanding of its essence, we have identified the following components: motivational-value, cognitive, activity, reflexive and regulatory. The study of these 
components allowed us to determine the criteria and indicators of socio-ecological knowledge and to make a level characteristic of its development. Based on our work on the study of socio-ecological knowledge, we have identified the following content of this concept. The socio-ecological knowledge of the future professor is the quality of a continuously developing personality with a professional and socio-ecological orientation, possessing socio-ecological knowledge, professional and personal skills, and reflexivity.

The development of the socio-ecological knowledge of the future professor is possible when creating a pedagogical system of continuous socio-ecological education of the future professor in the course of his professional training. The pedagogical system is the interrelation of the structural components of the educational process aimed at the development of the individual [12], where pedagogical conditions are its essential element. The condition is a component of phenomena and processes that affect the formation of the environment in which a certain phenomenon occurs. In the context of our study, pedagogical conditions are a set of purposefully created measures that ensure the preparation of future professors for continuous socio-ecological education. We have identified the following conditions:

- creating a socio-eco-oriented educational environment that reflects the external and internal relations of the university. The actual external relations are the interaction of the university with educational organizations, which are a certain platform for the practical training of future professors, as well as practicing professors;

- integration of formal, non-formal, and informal education, ensuring linear continuity, moving from one type of education to another. Thus, the process of formal education is the implementation of the Federal State Educational Standard of the "Pedagogical Education" field and filling the curriculum with disciplines of socioecological orientation, like "Social Ecology", "Ecological Pedagogy"," Fundamentals of Ecological Education", as well as filling the content of psychological and pedagogical disciplines with topics that reflect socio-ecological information. In the process of nonformal education, students (future professors) actively participated in leading pedagogical (School of Counselors, "Young Ecologist" School, etc.) and social practices (ecovolunteering, actions, etc.), as well as in training, environmental projects, scientific and practical conferences, etc. The possibilities of informal education related to self-education, improvement of the future professor as a fully developed personality in the field of social ecology and region ecology, were also used, which contributed to active attendance of socio-ecological events: visits to the nature museum, theater productions, exhibitions of photos, paintings on ecological issues, etc.;

- use of modern digital, information and communication, educational technologies in the professional training of future professors. The following technologies were actively used in the educational process: problem-based learning, case studies, collaborative learning, etc. The use of information and communication technologies provided variability in the training of students, namely the creation of ecological games, quests, crosswords using animation effects and interactive whiteboards, etc. Digital technologies are of particular interest in the conditions of modern realities. Thus, the electronic educational and methodological complex for the discipline "Social Ecology", developed using the Moodle system, includes lectures, practical tasks, socio-ecological tasks, tasks for independent work and control. The system advantages include automatic assessment and getting points for tests and completed tasks, as well as effective feedback from the professor and students. This system made it possible to organize remote and mixed training of students in this course.

The analysis of the papers allowed us to characterize the main concepts of the study, to identify the components of the socio-ecological knowledge of the future professor's personality, according to which the diagnostic tools were selected. 


\section{Results and Discussion}

Experimental work aimed at the implementation of pedagogical conditions to develop socio-ecological knowledge of the future professor was carried out based on the D.I. Mendeleev Tobolsk State Socio-Pedagogical Academy (branch of the Tyumen State University) and the Budgetary Institution of Higher Education of the Khanty-Mansiysk Autonomous Okrug-Yugra "Surgut State Pedagogical University", which was attended by 275 students of the "Pedagogical Education" field.

To study the level of development of socio-ecological knowledge, we used a set of methods for its selected components: motivational-value component - "Motivation of Professional Activity" method (K. Zamfir in the modification of A. Reana), "Alternative" method (S.D. Deriabo, V.A. Yasvin); cognitive component - test on "Determining the Level of Environmental Knowledge" (designed by the author); activity component "Ecological Competence of the Individual" questionnaire (A.V. Gagarin); "Ecological Culture" inventory (E.V. Asafova); reflexive component - "Professional Basket of the Teacher" (N.P. Nesgovorova, adapted version).

We will analyze the results of the control stage study in comparison with the results of the ascertaining stage. To determine the effectiveness of the influence of pedagogical conditions, we turn to the high-level results:

- according to the motivational-value component, there is an increase in respondents by $12.8 \%$ (from $33 \%$ to $45.8 \%$ ), who are characterized by: high internal motivation for professional activity, aesthetic and practical type of motivation, pedagogical and socioecological values expressed in subject-subject and socio-ecological relations, etc.;

- according to the cognitive component, there is an increase in respondents by $25.3 \%$ (from $38.6 \%$ to $13.3 \%$ ), who are characterized by systematic, deep socio-ecological knowledge about socio-ecological problems and ways to solve them, about socio-ecological interaction, about technologies and forms of socio-ecological education, etc.;

- $\quad$ according to the activity component, there is an increase in respondents by $25.5 \%$ (from 29.2 to $54.7 \%$ ), who are characterized by the ability to solve pedagogical and socioecological problems, the ability to analyze the ecological situation, design the activities of students, etc.;

- according to the reflexive-regulatory component, there is an increase in respondents by $25.4 \%$ (from $15 \%$ to $40.4 \%$ ), who are characterized by the skills of reflexive analysis of their own activities, design of self-development and self-education, self-realization in pedagogical activity.

All the presented results were processed using the method of mathematical statistics the Fisher criterion, which indicate that the level of development of socio-ecological knowledge for all components is significantly higher at the control stage than at the ascertaining stage.

\section{Conclusions}

Thus, the theoretical analysis of the psychological and pedagogical papers allowed us to identify the leading ideas in the field of continuous socio-ecological education to distinguish the significance of the pedagogical system of the university, to determine the forms, methods, conditions for the development of socio-ecological knowledge, the implementation of which showed the effectiveness of experimental work proved by the Fisher criterion, according to which the level of development of socio-ecological knowledge of future professors is significantly higher at the control stage than at the ascertaining stage. 
The results of the experimental study prove the effectiveness of the pedagogical system of the university, including the conditions, modern methods, and organizational forms of training and education that ensure the development of socio-ecological knowledge of the future professor, which is confirmed by quantitative, qualitative, and mathematical processing.

\section{References}

1. Niyazova, Pedagogy, 4, 81 (2021)

2. N. M. Ardoin, Environmental education and K-12 student outcomes: a review and analysis of research (2021)

3. O. Siegman, Global Environmental Change: Human and Policy Dimensions, 88 (2017)

4. C. Galvis-Riaño, F. Perales-Palacios, Y. Ladino-Ospina, Conceptions about the environment and environmental education by teachers from rural schools in BogotaColombia

5. E.V. Girusov. The Age of Globalization, 1 (2015)

6. V. S. Shilova, Int. J. of Experimental Education, 7, 158 (2015)

7. E. G. Sharonova, Bulletin of the Krasnoyarsk State Pedagogical University named after V.P. Astafiev (2011)

8. A. A. Niyazova, R. H. Shaimardanov, Method of designing the technology of continuous socio-ecological education of the future professor at the university, 58 (2020)

9. V. S. Shilova, V. B. Tarabaeva, N. L. Shechovska, M. S. Zhirov, S. I. Tarasova, Social Sciences (Pakistan), 11(10), 2429 (2016)

10. I. P. Safronov, Formation of ecological culture of the professor, 18 (1992)

11. L. S. Koldamasova, Formation of ecological knowledge of students in the process of professional training, 24 (2005)

12. A. N. Khuziakhmetov, R. Kh. Shaimardanov, Pedagogical technologies, 240 (2008) 